\title{
Push-out Bond Strength of Two Types of Dental Post Luted with Two Types of Cement at Two Different Root Levels
}

\section{Istisna čvrstoća veze dviju vrsta intrakanalnih kolčića pričvršćenih dvjema vrstama cementa na dvjema različitim razinama korijena}

Prosthodontics Unit, School of Dental Sciences, Health Campus, University Sains Malaysia, Kelantan, Malaysia

Odjel za stomatološku protetiku Škole stomatoloških znanost - Zdravstveni kampus Sveučilišta Sains Malezija, Kelantan, Malezija

\section{Abstract}

Objective: Endodontically treated teeth may require posts for retaining the core and replacing the coronal structures that have been lost. The objective of this study was to evaluate and compare the push-out bond strength between different types of post cemented with different types of luting cement at different types of root level. Material and Methods: In this in-vitro study, a total of 48 singlerooted permanent human teeth were decoronated, and the roots were treated endodontically. Following post space preparation, the sample was divided into four groups $(n=12$ each) based on the types of post and cement. Two different types of post [GC everStick ${ }^{\circledR}$ POST (ES) and Parapost ${ }^{\circledR}$ Fiber Lux $\left.^{\mathrm{TM}}(\mathrm{PF})\right]$, and two different types of cement [G-CEM ${ }^{\mathrm{TM}}(\mathrm{G})$, and RelyX $\mathrm{X}^{\mathrm{TM}}$ Unicem (R)] were used according to the manufacturer's instructions. All roots were sectioned at the coronal and middle thirds with a thickness of $3 \pm 0.1 \mathrm{~mm}$. The Push-out bond strength (PBS) test was performed using a universal testing machine at a cross-head speed of $0.5 \mathrm{~mm} / \mathrm{min}$. The bond strength values were recorded, and the data were analyzed using the SPSS program. Apart from descriptive statistics, three-way ANOVA was used for the interaction of the independent variables (post, cement, and root level). For differences between the groups, the Mann-Whitney $U$ test was used. A P-value of less than 0.05 was considered significant for all analyses. Results: Push-out bond strength of samples at the middle level $(11.38 \pm 10.31 \mathrm{MPa})$, with PF posts $(11.18 \pm 9.98 \mathrm{MPa})$, and of those luted with Rely $\mathrm{X}^{\mathrm{TM}}$ Unicem cement $\left(13.26 \pm 8.73 \mathrm{MPa}\right.$ ) was higher than that of their counterparts. The PBS means of RelyX $\mathrm{X}^{\mathrm{TM}}$ Unicem cement at both root levels were much higher than PBS means of G-CEM ${ }^{\top M}$ cement. Three-way ANOVA test revealed a significant effect for each variable with a higher effect of cement (Sum of Squares= 1310.690; $P<0.001)$. No significant difference $(P=0.153)$ was found between the coronal and middle parts and between $E S$ and $P F$ posts $(P=0.058)$. However, a highly significant difference $(P<0.001)$ was found between RelyX $X^{\top M}$ Unicem and G-CEM ${ }^{\top M}$ cements. Conclusion: The type of cement had a significant effect on push-out bond strength with Rely $X^{\text {TM }}$ Unicem which had higher values than G-CEM ${ }^{\text {TM }}$. However, the type of post and root level had no significant effect on PBS, although Parapost ${ }^{\circledR}$ Fiber Lux $^{\mathrm{TM}}$ and middle root level had higher values than their counterparts.
Received: April 29, 2020

Accepted: June 24, 2020

Address for correspondence Associate Professor Zaihan Ariffin, DClin Dentistry

School of Dental Sciences, Health Campus,

University Sains Malaysia, 16150 Kubang Kerian,

Kelantan, Malaysia

zaihan@usm.my
Key words

Dental Cements; Dentin-Bonding Agents; Bond Strength; Post and Core Technique

\section{Introduction}

Endodontically treated teeth have a reduced stiffness due to factors such as reduced moisture content of the tooth as well as the destruction of the coronal region of the tooth as a result of extensive dental caries [1], and this, in turn, increases the possibility of tooth fracture during function [2]. Thus, post systems have been introduced for retaining the core that replaces the lost coronal structures [3]. These systems have been used in clinical settings for many years [4]. The limitations of conventional metallic posts have been overcome by the development of fiber post whereby the posts flexibility has been increased, and a similar modulus of elasticity as dentin is achieved [5, 6]. Apart from elastic modulus, fiber posts also enhance several other superior properties such as high tensile strength, high fatigue, ability to be cemented with adhesive
Uvod

Endodontski liječeni zubi manje su kruti zbog čimbenika poput smanjenog sadržaja vlage u zubu te destrukcije krune kao posljedice opsežnog zubnog karijesa (1), a to zauzvrat povećava mogućnost lomljenja zuba tijekom funkcije (2). Zato su uvedeni sustavi intrakanalnih kolčića za retenciju krunskog dijela nadogradnje koja nadomješta izgubljeno zubno tkivo (3). Ti su sustavi u kliničkoj primjeni već godinama (4). Ograničenja konvencionalnih metalnih nadogradnji prevladala su se pojavom kompozitnih kolčića ojačanih vlakanima, pa se povećala njihova fleksibilnost i postigao modul elastičnosti sličan dentinu $(5,6)$. Osim modula elastičnosti, kolčići ojačani vlaknima imaju i druga povoljna svojstva, kao što su velika vlačna čvrstoća i mogućnost adhezijskog cementiranja da bi se izbjegla pojava trenja između kolčića i stijenki ko- 
luting material to avoid friction development in between the posts and the walls of the root canal, thus leading to equal distribution of the force applied along the length of the post [7]. More than $90 \%$ success rates with zero root fracture incidence have been reported by clinical studies on restorations with fiber posts during the study duration [8]. On the other hand, it has been found that the most common failure was due to lack of retention of the fiber posts [9]. A fiber post is composed of a high percentage volume of continuous fibers that are embedded in a polymer matrix [10]. They are readily cured, and the matrix may be either a cross-linked epoxy resin matrix or a Bis-GMA matrix along with some fillers content [11]. The fiber content offers high tensile properties to the post, while the resin matrix plays a role in resisting compressive stresses [12, 13]. According to Baran et al., the incidence of post fracture in clinical settings is associated with the mechanical properties of the post itself [14]. In general, there are several factors that contribute to the mechanical strength of a fiber post and they include the individual properties of the fiber and matrix, polymerization shrinkage of the resin, intracanal irrigation systems, bonding between the fibers and matrix resin, the direction of the fibers as well as the volume fraction and proportion of fibers that were being impregnated into the resin matrix $[11,15,16]$. The retention of fiber posts is depended on bond strength between the resin luting agent and the post and also the bond strength between the dentin and the resin luting agent [17]. When a successful bonding is achieved, it will minimize the wedging effect of the post in the root canal, thus reducing the risk of tooth fracture [18].

The effects of cement on the retention of the post have been widely investigated, and it was proved that the use of resin cements could significantly increase the retentive rate and fractural resistance of the tooth by providing adhesive bonding [2]. Various types of luting cement and adhesive systems are available for fiber post luting. They can be categorized into two main groups: self-etch and etch-and-rinse adhesive systems [19]. In this regard, several studies have been conducted to compare the effects of self-etch and etch-andrinse adhesive systems on the bond strength of fiber posts to root canal dentin. The push-out test has been used to evaluate the bonding of posts to root canal dentin. This test can provide a more accurate and better estimation of bonding strength compared to the conventional shear test because the fracture occurs parallel to the dentin-bonding interface, thus making it a true shear test. The Push-out test is also believed to be more reliable than a micro tensile test for bonded posts since the micro tensile test has been highly associated with large data distributions as well as a high number of premature failures that occur during specimen preparation. Apart from that, the Push-out test is also said to more closely simulate clinical conditions [20].

Since there are still considerably fewer data available in the literature regarding the differences on the bond strength of resin cement on everStick fiber post and indirect fiber composite post [21-23], this study was conducted to evaluate and compare the push-out bond strength between different types of posts cemented with different types of luting cement at two different levels of the root. rijenskog kanala, čime se postiže ravnomjerna raspodjela sile duž kolčića (7). U kliničkim istraživanjima o restauracijama $s$ kolčićima ojačanima vlaknima zabilježene su stope uspjeha veće od $90 \%$ bez incidencije fraktura korijena (8). S druge strane, ustanovljeno je da je razlog za neuspjeh najčešće manjkava retencija kolčića (9). Kolčić se sastoji od gusto raspoređenih kontinuiranih vlakana ugrađenih u polimernu matricu (10). Matrica može biti ili umreženi matriks epoksidne smole ili bis-GMA s određenim udjelom punila (11). Sadržaj vlakana osigurava kolčiću vlačnu čvrstoću, a smolasta matrica omogućuje otpornost na tlačne sile $(12,13)$. Prema Baranu i suradnicima učestalost lomljenja u kliničkim uvjetima povezana je s mehaničkim svojstvima samog kolčića (14) Općenito, postoji nekoliko čimbenika koji pridonose mehaničkoj čvrstoći kolčića ojačanog vlaknima, a uključuju individualna svojstva vlakana i matrice, polimerizacijsko skupljanje smole, sustav intrakanalnog ispiranja, vezu između vlakana i smole, smjer vlakana te volumni udio i udio vlakana koja su impregnirana u smolastu matricu $(11,15,16)$. Retencija kolčića ovisi o veznoj čvrstoći između cementa i kolčića, a i između dentina i cementa (17). Kada se postigne uspješno vezivanje, to umanjuje učinak klina kolčića u korijenskom kanalu, smanjujući na taj način rizik od lomljenja zuba (18).

Učinak cementa na retenciju kolčića naširoko je istražen i dokazano je da adhezijski cement može, osiguravanjem adhezijske veze, znatno povećati retenciju i otpornost zuba na frakturu (2). Na tržištu se mogu nabaviti različite vrste cemenata i adhezijskih sustava za cementiranje kompozitnih kolčića ojačanih vlaknima. Mogu se svrstati u dvije glavne skupine: samojetkajući adhezijski sustavi i jetkajuće-ispirući sustavi (19). Provedeno je nekoliko istraživanja u kojima su autori uspoređivali učinke samojetkajućih i jetkajuće-ispirućih adhezijskih sustava na veznu čvrstoću kompozitnih kolčića na dentin korijenskog kanala. Za procjenu je upotrijebljen vlačni test. Tim se testom može preciznije i bolje procijeniti vezna čvrstoća u usporedbi $s$ konvencionalnim posmičnim testom jer se fraktura događa paralelno sa sučeljem veze s dentinom. Vjeruje se da je vlačni test pouzdaniji od mikrovlačnoga testa za cementirane kolčiće jer je mikrovlačni test povezan $s$ velikom distribucijom podataka i velikim brojem preuranjenih lomova koji se pojavljuju tijekom pripreme uzorka. Uz to, smatra se da vlačni test također pobliže simulira klinička stanja (20).

Budući da je u literaturi još uvijek znatno manje podataka o razlikama vezne čvrstoće cementa s kolčićima everStick i indirektnim kompozitnim kolčićima ojačanim vlaknima (21 --23), ovo je istraživanje provedeno da bi se procijenila i usporedila vezna čvrstoće pri povlačenju između različitih vrsta kolčića cementiranih različitim vrstama adhezijskih cemenata na dvjema različitim razinama korijena. 


\section{Material and methods}

This in-vitro study was conducted in the Craniofacial Laboratory of School of Dental Sciences, Health Campus, University Sains Malaysia. Ethical approval for this study was obtained from the Ethics Committee (USM/JEPeM/18010029). A total of 48 single-rooted human permanent teeth were selected according to the inclusion criteria: a) Extracted human teeth with 15-16 mm straight single-rooted canal with mature apices, b) Extraction was due to periodontal or orthodontic reasons, and c) Minimal caries with sound coronal structure. The exclusion criteria were: a) Teeth with extensive caries (extend beyond the cementoenamel junction), and b) Teeth with extra canals, open apices, calcified canals, or curved roots. All soft tissues and debris around the teeth were removed using an ultrasonic scaler, and teeth were then stored in normal saline to prevent dehydration until the period of study. The materials used in this study are listed in Table 1. The teeth were randomly divided into four groups ( $\mathrm{n}=12$ each) as follows: Group 1 (PF-G): Parapost Fiber Lux ${ }^{\mathrm{TM}}$ luted with G- CEM ${ }^{\mathrm{TM}}$, Group 2 (PF-R): Parapost Fiber Lux ${ }^{\mathrm{TM}}$ luted with RelyX $\mathrm{X}^{\mathrm{TM}}$ Unicem, Group 3 (ESG): GC everStick POST luted with G- CEM $^{\mathrm{TM}}$, and Group 4 (ES-R): GC everStick POST luted with RelyX ${ }^{\mathrm{TM}}$ Unicem. Working length was standardized to $15 \pm 1 \mathrm{~mm}$ [24, 25].

The access cavity was prepared using an endodontic access bur. The pulp tissue was removed using a barbed broach (Dentsply Maillefer, Switzerland). Apical patency was verified by passing ISO size 10 and $15 \mathrm{~K}$-file (Dentsply Maillefer, Switzerland) through the root canal until the tip of the file was visible at the apical foramen. The irrigation of root canal filling was done by using normal saline and sodium hypochlorite solution. The length was then reduced by $1 \mathrm{~mm}$ from the original working length. The canal was prepared with Universal Protaper (Dentsply Maillefer, Switzerland) using the crown down technique (S2 file size) and flaring of the canal was done using a F2 finishing file size. The final irrigation was done with normal saline solution after the irrigation to remove any remaining debris in the root canal after preparation. All canals were then dried with absorbent paper points. Obturation was done using a single Protaper' Universal Gutta Percha size F2 with AH Plus sealer.

After that, a gutta-percha on the coronal and middle thirds of each root was removed using low-speed Gates Glidden drills number 2 and 3 (Dentsply Maillefer, Switzerland), leaving $5 \mathrm{~mm}$ of intact gutta-percha to preserve the apical seal. A radiograph was taken for each tooth to ensure that there is no gutta-percha remains on the coronal and middle third sections of each root. Before the cementation procedure, the post space was irrigated with normal saline and dried with paper points. Both types of posts were then cemented with G- CEM $^{\mathrm{TM}}$ (GC Corp., Tokyo, Japan) or RelyX ${ }^{\mathrm{TM}}$ Unicem (Coltene, Whaledent, USA) following the manufacturer's instructions. The teeth were then sectioned perpendicular to the long axis of the tooth using a hard tissue cutter (Exact apparatebau, Germany) at the coronal and middle levels of the root with $3 \pm 0.1 \mathrm{~mm}$ thickness [26]. The push-out bond strength test of the samples was then performed with a uni-

\section{Materijali i metode}

Ovo istraživanje in vitro provedeno je u kraniofacijalnom laboratoriju Škole stomatoloških znanosti u Zdravstvenom kampusu Sveučilišta Sains u Maleziji. Odobrilo ga je Etičko povjerenstvo (USM/JEPeM/18010029). Odabrano je ukupno 48 jednokorijenskih ljudskih trajnih zuba u skladu s kriterijima za uključivanje: a) izvađeni zub s jednim ravnim kanalom dužine od 15 do $16 \mathrm{~mm}$ i zrelim apeksom; b) vađenje zbog parodoloških ili ortodontskih razloga; c) minimalni karijes sa zdravim koronarnim tkivom.

Kriteriji za isključivanje bili su: a) zubi s opsežnim karijesom (koji se proteže preko caklinsko-cementnog spojišta); b) zubi s dodatnim kanalima, otvorenim apeksom, kalcificiranim kanalima ili zakrivljenim korijenima.

Sva meka tkiva i nečistoće oko zuba uklonjeni su ultrazvučnim strugačem, a zubi su zatim pohranjeni u fiziološku otopinu da bi se spriječila dehidracija do razdoblja ispitivanja. Materijali korišteni u ovom istraživanju navedeni su u tablici 1. Zubi su nasumično podijeljeni u četiri skupine ( $\mathrm{n}=12$ svaka) kako slijedi: skupina 1 (PF-G): Parapost Fiber Lux ${ }^{\mathrm{TM}}$ pričvršćen cementom G-CEM ${ }^{\mathrm{TM}}$; skupina 2 (PF-R): Parapost Fiber Lux ${ }^{\mathrm{TM}}$ pričvršćen cementom RelyX ${ }^{\mathrm{TM}}$ Unicem; skupina 3 (ES-G): GC everStick'POST pričvršćen cementom G$\mathrm{CEM}^{\mathrm{TM}}$; i skupina 4 (ES-R): GC everStick POST pričvršćen cementom RelyX ${ }^{\mathrm{TM}}$ Unicem. Radna dužina standardizirana je na $15 \pm 1 \mathrm{~mm}(24,25)$.

Pristupni kavitet prepariran je endodontskim svrdlom. Pulpno tkivo uklonjeno je pulpekstirpatorom (Dentsply Maillefer, Švicarska). Apikalno brtvljenje provjereno je prolaskom instrumenata ISO veličine 10 i 15 (Dentsply Maillefer, Švicarska) kroz korijenski kanal sve dok njegov vrh nije bio vidljiv na apikalnom otvoru. Korijenski kanal ispiran je fiziološkom otopinom i otopinom natrijeva hipoklorita. Dužina je zatim smanjena za $1 \mathrm{~mm}$ od prvotne radne duljine. Kanal je strojno obrađen uređajem Universal Protaper (Dentsply Maillefer, Švicarska) primjenom tehnike crown down (veličina instrumenta S2), a završeno je instrumentom F2. Za završno ispiranje upotrijebljena je fiziološka otopina da bi se uklonila zaostala nečistoća iz korijenskog kanala nakon instrumentacije. Svi su kanali zatim osušeni papirnatim štapićima. Za opturaciju je korištena jedna gutaperka Protaper Universal veličine F2 i cement AH Plus.

Nakon toga je gutaperka iz koronarne i srednje trećine svakog korijena uklonjena svrdlima Gates Glidden broj 2 i 3 (Dentsply Maillefer, Švicarska) uz mali broj okretaja, ostavljajući $5 \mathrm{~mm}$ intaktne gutaperke da bi se sačuvao apikalni pečat. Svaki je zub rendgenski snimljen kako bi se provjerilo da u koronarnoj i srednjoj trećini svakog korijena nema ostataka gutaperke. Prije postupka cementiranja intrakanalni prostor ispran je fiziološkom otopinom i osušen papirnatim štapićima. Obje vrste kolčića zatim su zacementirane cementima G$\mathrm{CEM}^{\mathrm{TM}}$ (GC Corp., Tokio, Japan) ili RelyX ${ }^{\mathrm{TM}}$ Unicem (Coltene, Whaledent, SAD) slijedeći upute proizvođača. Zubi su zatim prerezani okomito na njihovu uzdužnu osovinu rezačem tvrdog tkiva (Exact apparatebau, Njemačka) na koronalnoj i srednjoj razini korijena na debljinu od $3 \pm 0,1 \mathrm{~mm}$ (26). Ispitivanje vlačne čvrstoće uzoraka obavljeno je univer- 
versal testing machine (Instron Corp., UK) at a cross-head speed of $0.5 \mathrm{~mm} / \mathrm{min}$. The force in Newton was applied, and the peak reading was recorded when a failure occurred. The readings were transferred to a master sheet, and the following formula was applied for the push-out bond strength:

$$
\text { Push-out bond strength }(\mathrm{PBS})=\frac{\operatorname{Force}(N)}{\pi(r 1-r 2) \sqrt{(r 1+r 2)^{2} \times h^{2}}}
$$

where $\mathrm{r} 1$ : is the radius of the post from the upper part of the specimen, $\mathrm{r} 2$ : is the radius of the post from the lower part of the specimen, and $h$ : is the height of the specimen.

The data were analyzed using the SPSS software program for Windows Version 25.0. Descriptive statistics in terms of means, standard deviations, minimum and maximum were presented. Factorial 3-way ANOVA test was used for the interaction of the three independent factors (post, cement, and root level). For differences between the groups, the MannWhitney $U$ test was used. A P-value of less than 0.05 was considered significant for all tests.

\section{Results}

Table 1 shows the descriptive results of the PBS of the samples by type of post, type of cement, root level, and groups. In general, it can be noticed that the PBS means of at the middle level $(11.38 \pm 10.31 \mathrm{MPa})$, Parapost Fiber Lux ${ }^{\mathrm{TM}}$ post group $(11.18 \pm 9.98 \mathrm{MPa})$, and Rely $\mathrm{X}^{\mathrm{TM}}$ cement group $(13.26 \pm 8.73 \mathrm{MPa})$ were higher than that of their counterparts. For sub-groups, samples cemented with RelyX ${ }^{\mathrm{TM}}$ cement (regardless of the type of the post) were more retentive than those cemented with G- CEM ${ }^{\mathrm{TM}}$ cement $(\mathrm{PF}-\mathrm{R}=$ $14.52 \pm 10.62 \mathrm{MPa}$ and $\mathrm{ES}-\mathrm{R}=11.99 \pm 6.30 \mathrm{MPa}$ compared to $P F-G=7.84 \pm 8.21 \mathrm{MPa}$ and $E S-G=3.90 \pm 6.57 \mathrm{MPa}$ ). When the PBS was calculated for the groups at each root level (Table 2), the results revealed that the PBS means of the ES post and PF post were close to each other at the coronal level (6.62 $\pm 7.33 \mathrm{MPa}$ and $8.88 \pm 6.64 \mathrm{MPa}$, respectively). However, at the middle level, the PBS of PF post was much higher than that of ES post. The PBS means of Rely $\mathrm{X}^{\mathrm{TM}}$ cement at both root levels were much higher than PBS means of G- zalnom kidalicom (Instron Corp., UK) brzinom od 0,5 mm/ min. Primijenjena je sila u njutnima, a očitana je vršna sila u trenutku frakture. Očitanja su prenesena na glavni list, a za izračun lomne sile primijenjena je sljedeća jednadžba:

$$
\text { Vlačna čvrstoća }(\mathrm{PBS})=\frac{\operatorname{Sila}(N)}{\pi(r 1-r 2) \sqrt{(r 1+r 2)^{2} \times h^{2}}}
$$

gdje je r1: promjer kolčića na gornjem dijelu uzorka, r2: je promjer kolčića na donjem dijelu uzorka, a h: visina uzorka.

Podatci su analizirani u softverskom programu SPSS za Windowse, verzija 25.0. Prikazana je deskriptivna statistika u obliku srednjih vrijednosti, standardnih devijacija te minimalnih i maksimalnih vrijednosti. Faktorski trodimenzionalni ANOVA test upotrijebljen je za interakciju triju neovisnih čimbenika (kolčić, cement i razina korijena). Za razlike među skupinama korišten je Mann-Whitneyjev U-test. P-vrijednost manja od 0,05 smatrala se značajnom za sva ispitivanja.

\section{Rezultati}

U tablici 1. su deskriptivni rezultati PBS-a uzoraka prema vrsti kolčića, vrsti cementa, razini korijena i skupini. Općenito se može uočiti da su srednje vrijednosti PBS-a na srednjoj razini $(11,38 \pm 10,31 \mathrm{MPa})$ u skupini Parapost Fiber Lux $^{\mathrm{TM}}$ $(11,18 \pm 9,98 \mathrm{MPa})$ i cementna skupina RelyX ${ }^{\mathrm{TM}}(13,26 \pm$ $8,73 \mathrm{MPa}$ ) bile veće u usporedbi s ostalima. U podskupinama su uzorci pričrvšćeni cementom RelyX $\mathrm{X}^{\mathrm{TM}}$ (bez obzira na vrstu kolčića) imali bolju retenciju od onih pričvršćenih cementom G-CEM ${ }^{\mathrm{TM}}(\mathrm{PF}-\mathrm{R}=14,52 \pm 10,62 \mathrm{MPa}$ i ES-R $=$ $11,99 \pm 6,30 \mathrm{MPa}$ u usporedbi $s \mathrm{PF}-\mathrm{G}=7,84 \pm 8,21 \mathrm{MPa}$ i $\mathrm{ES}-\mathrm{G}=3,90 \pm 6,57 \mathrm{MPa}$ ). Kad je izračunat PBS za skupine na svakoj razini korijena (tablica 2.), rezultati su pokazali da su srednje vrijednosti PBS-a za kolčiće ES i PF bile blizu jedne drugima na koronarnoj razini $(6,62 \pm 7,33 \mathrm{MPa}$ i $8,88 \pm 6,64 \mathrm{MPa})$. No na srednjoj razini bio je PBS za kolčiće PF mnogo veći negoli za ES. Srednje vrijednosti PBS-a za cement RelyX ${ }^{\mathrm{TM}}$ na objema razinama korijena bile su mnogo veće negoli za G-CEM ${ }^{\mathrm{TM}}$. U podskupinama na koronar-

Table 1 Means and SDs of push-out bond strength by root level, type of post, type of cement, and by subgroup

\begin{tabular}{|c|c|c|c|c|c|}
\hline & $\mathbf{N}$ & $\begin{array}{c}\text { Mean } \bullet \\
\text { Srednja vrijednost }\end{array}$ & SD & Minimum & $\begin{array}{l}\text { Maximum • } \\
\text { Maksimum }\end{array}$ \\
\hline \multicolumn{6}{|c|}{ Root level • Razina korijena } \\
\hline Coronal $\bullet$ Koronarna & 48 & 7.75 & 7.01 & 0.12 & 26.59 \\
\hline Middle $\bullet$ Srednja & 48 & 11.38 & 10.31 & 0.05 & 48.46 \\
\hline \multicolumn{6}{|c|}{ Type of post $\bullet$ Vrsta kolčića } \\
\hline Fiber & 48 & 11.18 & 9.98 & 0.12 & 48.46 \\
\hline EverStick & 48 & 7.94 & 7.57 & 0.05 & 29.19 \\
\hline \multicolumn{6}{|c|}{ Type of cement $\bullet$ Vrsta cementa } \\
\hline Rely-X & 48 & 13.26 & 8.73 & 0.28 & 48.46 \\
\hline G-CEM & 48 & 5.87 & 7.62 & 0.05 & 26.59 \\
\hline \multicolumn{6}{|c|}{ Subgroup $\bullet$ Podskupina } \\
\hline PF-R & 24 & 14.52 & 10.62 & 0.28 & 48.46 \\
\hline PF-G & 24 & 7.84 & 8.21 & 0.12 & 24.80 \\
\hline ES-R & 24 & 11.99 & 6.30 & 0.91 & 29.19 \\
\hline ES-G & 24 & 3.90 & 6.57 & 0.05 & 26.59 \\
\hline
\end{tabular}

Tablica 1. Srednje vrijednosti i standardne devijacije prema razini korijena, vrsti kolčića, vrsti cementa i podskupini 
Table 2 Push-out bond strength by type of post, type of cement, and by subgroup at each root level

Tablica 2. Vlačna čvrstoća prema vrsti kolčića, vrsti cementa i podskupini na svakoj razini korijena

\begin{tabular}{|c|c|c|c|c|c|c|}
\hline & & $\mathbf{N}$ & $\begin{array}{c}\text { Mean } \bullet \text { Srednja } \\
\text { vrijednost }\end{array}$ & SD & Minimum & $\begin{array}{l}\text { Maximum • } \\
\text { Maksimum }\end{array}$ \\
\hline \multicolumn{7}{|c|}{ Root level • Razina korijena } \\
\hline & Post & & & & & \\
\hline \multirow{2}{*}{$\begin{array}{l}\text { Coronal • } \\
\text { Koronarna }\end{array}$} & Parapost & 24 & 6.62 & 7.33 & 0.12 & 24.58 \\
\hline & EverStick & 24 & 8.88 & 6.64 & 0.68 & 26.59 \\
\hline \multirow{2}{*}{$\begin{array}{l}\text { Middle • } \\
\text { Srednja }\end{array}$} & Parapost & 24 & 15.75 & 10.31 & 2.54 & 48.46 \\
\hline & EverStick & 24 & 7.01 & 8.44 & 0.05 & 29.19 \\
\hline \multicolumn{7}{|c|}{ Root level • Razina korijena } \\
\hline & Cement & & & & & \\
\hline \multirow{2}{*}{$\begin{array}{l}\text { Coronal • } \\
\text { Koronarna }\end{array}$} & Rely-X & 24 & 10.83 & 5.93 & 0.28 & 24.58 \\
\hline & G-CEM & 24 & 4.67 & 6.75 & 0.12 & 26.59 \\
\hline \multirow{2}{*}{$\begin{array}{l}\text { Middle • } \\
\text { Srednja }\end{array}$} & Rely-X & 24 & 15.69 & 10.41 & 0.91 & 48.46 \\
\hline & G-CEM & 24 & 7.07 & 8.38 & 0.05 & 24.80 \\
\hline \multicolumn{7}{|c|}{ Root level • Razina korijena } \\
\hline & Subgroup & & & & & \\
\hline \multirow{4}{*}{$\begin{array}{l}\text { Coronal • } \\
\text { Koronarna }\end{array}$} & PF-R & 12 & 10.88 & 7.63 & 0.28 & 24.58 \\
\hline & PF-G & 12 & 2.36 & 3.83 & 0.12 & 14.29 \\
\hline & ES-R & 12 & 10.78 & 3.92 & 2.77 & 15.24 \\
\hline & ES-G & 12 & 6.97 & 8.30 & 0.68 & 26.59 \\
\hline \multirow{4}{*}{$\begin{array}{l}\text { Middle • } \\
\text { Srednja }\end{array}$} & PF-R & 12 & 18.16 & 12.19 & 2.54 & 48.46 \\
\hline & PF-G & 12 & 13.33 & 7.79 & 3.24 & 24.80 \\
\hline & ES-R & 12 & 13.21 & 8.03 & 0.91 & 29.19 \\
\hline & ES-G & 12 & 0.82 & 0.86 & 0.05 & 2.68 \\
\hline
\end{tabular}

Table 3 Factorial 3-way ANOVA for the interaction effect of the independent variables (root level, post, cement)

Tablica 3. Faktorska trosmjerna ANOVA za učinak interakcije neovisnih varijabli (razina korijena, kolčić, cement)

\begin{tabular}{|c|c|c|c|c|c|}
\hline Source $\bullet$ Izvor & $\begin{array}{c}\text { Type III Sum of Squares } \\
\text { Tip III Suma kvadrata }\end{array}$ & $\begin{array}{c}\text { df } \bullet \\
\text { Stupanj } \\
\text { slobode }\end{array}$ & $\begin{array}{l}\text { Mean Square • } \\
\text { Srednji kvadrat }\end{array}$ & $\mathbf{F}$ & $\mathbf{P}$ \\
\hline \multirow[t]{2}{*}{ Corrected Model $\bullet$ Korigirani model } & 2877.035 & 7 & 411.005 & 7.618 & 0.000 \\
\hline & 8780.288 & 1 & 8780.288 & 162.739 & 0.000 \\
\hline Root level $\bullet$ Razina korijena & 316.318 & 1 & 316.318 & 5.863 & 0.018 \\
\hline Post • kolčić & 251.619 & 1 & 251.619 & 4.664 & 0.034 \\
\hline Cement & 1310.690 & 1 & 1310.690 & 24.293 & 0.000 \\
\hline Root level * Post • Razina korijena * kolčić & 724.571 & 1 & 724.571 & 13.430 & 0.000 \\
\hline Root level ${ }^{*}$ Cement $\bullet$ Razina korijena ${ }^{*}$ cement & 35.966 & 1 & 35.966 & 0.667 & 0.416 \\
\hline Post ${ }^{*}$ Cement $\bullet$ Kolčić $^{*}$ cement & 12.042 & 1 & 12.042 & 0.223 & 0.638 \\
\hline Root level ${ }^{*}$ Post ${ }^{*}$ Cement $\bullet$ Razina korijena ${ }^{*}$ kolčić ${ }^{*}$ cement & 225.829 & 1 & 225.829 & 4.186 & 0.044 \\
\hline Error • Pogreška & 4747.872 & 88 & 53.953 & & \\
\hline Total • Ukupno & 16405.194 & 96 & & & \\
\hline Corrected Total $\bullet$ Korigirano ukupno & 7624.906 & 95 & & & \\
\hline
\end{tabular}

$\mathrm{P}<0.05$ is statistically significant $\bullet \mathrm{P}<0.05$ je statistički značajno

$\mathrm{CEM}^{\mathrm{TM}}$ cement. For sub-groups at the coronal level, posts luted with Rely-X cement (regardless of the type of post) had more PBS than those luted with G-CEM ${ }^{\mathrm{TM}}$ cement. However, at the middle level, PF posts luted with G-CEM ${ }^{\mathrm{TM}}$ cement had a retentive force almost similar to that of ES posts luted with RelyX ${ }^{\mathrm{TM}}$ Unicem cement, while PF posts luted with Rely $\mathrm{X}^{\mathrm{TM}}$ Unicem cement had much more retentive force than that of ES posts luted with G-CEM ${ }^{\mathrm{TM}}$ cement.

Three-way ANOVA test for the interaction effect of the independent variables (post, cement, and root level) revealed a significant effect for each variable (Table 3) with a higher noj razini imali su kolčići pričvršćeni cementom RelyX (bez obzira na vrstu kolčića) veće vrijednosti PBS-a od onih pričvršćenih cementom G-CEM ${ }^{\mathrm{TM}}$. No na srednjoj su razini postigli PF kolčići pričvršćeni cementom G-CEM ${ }^{\mathrm{TM}}$ retencijsku silu sličnu kolčićíma $\mathrm{ES}$ pričvršćenima cementom Rely $\mathrm{X}^{\mathrm{TM}}$ Unicem, a kolčići PF pričvršćeni cementom Rely $\mathrm{X}^{\mathrm{TM}}$ Unicem imali su mnogo veću retencijsku silu od kolčića ES pričvršćenih cementom G-CEM ${ }^{\mathrm{TM}}$.

Trosmjerna ANOVA za utjecaj interakcije neovisnih varijabli (kolčić, cement i razina korijena) pokazala je značajan učinak za svaku varijablu (tablica 3.) s većim učinkom ce- 
effect of cement (Sum of Squares=1310.690; $\mathrm{P}<0.001$ ). The interaction effect of the three variables was also significant $(\mathrm{P}=0.044)$. Table 4 shows the difference between the groups among the independent variables. No significant difference $(P=0.153)$ was found between the coronal and middle parts based on the root level. Similarly, no significant difference $(P=0.058)$ was found between $E S$ and PF posts based on the type of the post. However, a highly significant difference $(\mathrm{P}<$ 0.001 ) was found between RelyX ${ }^{\mathrm{TM}}$ Unicem and G- CEM ${ }^{\mathrm{TM}}$ cements based on the type of cement. menta (zbroj kvadrata $=1310.690 ; \mathrm{P}<0,001)$. Učinak interakcije triju varijabli također je bio značajan $(\mathrm{P}=0,044)$. Tablica 4. prikazuje razliku između skupina za neovisne varijable. Nije ustanovljena značajna razlika $(P=0,153)$ između koronarnog i srednjeg dijela. Slično tomu, nije pronađena značajna razlika $(\mathrm{P}=0,058)$ između kolčića ES i $\mathrm{PF}$. No postojala je značajna razlika $(\mathrm{P}<0,001)$ između cemenata RelyX $\mathrm{X}^{\mathrm{TM}}$ Unicem i G-CEM ${ }^{\mathrm{TM}}$.

\begin{tabular}{|c|c|c|c|c|c|c|c|}
\hline & \multirow[t]{2}{*}{$\mathrm{N}$} & \multirow{2}{*}{$\begin{array}{c}\text { Mean } \\
\text { Srednja vrijednost }\end{array}$} & \multirow{2}{*}{$\begin{array}{c}\text { Std. Deviation • } \\
\text { Std. devijacija }\end{array}$} & \multirow{2}{*}{$\begin{array}{c}\text { Mean Difference } \\
\text { Srednja razlika }\end{array}$} & \multicolumn{2}{|c|}{$\begin{array}{c}\text { 95\% CI of the Difference } \\
\text { 95\% IP razlike }\end{array}$} & \multirow[t]{2}{*}{$\mathbf{P}$} \\
\hline & & & & & Lower • donji & Upper • gornji & \\
\hline Coronal • Koronarna & 48 & 7.75 & 7.01 & \multirow[t]{2}{*}{-3.63} & \multirow[t]{2}{*}{-7.21} & \multirow[t]{2}{*}{-0.05} & \multirow[t]{2}{*}{0.153} \\
\hline Middle $\bullet$ Srednja & 48 & 11.38 & 10.31 & & & & \\
\hline Parapost & 48 & 11.18 & 9.98 & \multirow[t]{2}{*}{3.24} & \multirow[t]{2}{*}{-0.35} & \multirow[t]{2}{*}{6.83} & \multirow[t]{2}{*}{0.058} \\
\hline EverStick & 48 & 7.94 & 7.57 & & & & \\
\hline Rely-X & 48 & 13.26 & 8.73 & \multirow[t]{2}{*}{7.39} & \multirow[t]{2}{*}{4.07} & \multirow[t]{2}{*}{10.71} & \multirow[t]{2}{*}{0.000} \\
\hline G-CEM & 48 & 5.87 & 7.62 & & & & \\
\hline
\end{tabular}

\section{Discussion}

The results obtained in the present study showed that Parapost Fiber Lux ${ }^{\mathrm{TM}}$ and Rely $\mathrm{X}^{\mathrm{TM}}$ Unicem cement had recorded a higher push-out bond strength than GC everStick'POST and G- CEM ${ }^{\mathrm{TM}}$ cement. Thus, the results of this in-vitro study require the rejection of the null hypothesis since there are significant differences in push-out bond strength that exist between different luting cements. A research conducted by Yahya et al. also showed that the highest bond strength was attained by Rely $\mathrm{X}^{\mathrm{TM}}$ Unicem as compared to Elite $100^{\circ}$ zinc phosphate cement, Calibra and RelyX ARC resin cement [27]. Apart from that, a good bond strength was obtained for Rely $\mathrm{X}^{\mathrm{TM}}$ Unicem [28]. There are many possible explanations behind the superior bond strength of Rely $\mathrm{X}^{\mathrm{TM}}$ Unicem as compared to several other luting cements. The main possible reason may be the self-adhesive properties of Rely $\mathrm{X}^{\mathrm{TM}}$ Unicem due to the multifunctional phosphoric acid methacrylate material content, which is acidic and is able to cause demineralization of the tooth surface. This demineralization process is then followed by infiltration of the cements to the tooth structure and formation of chemical bonds with the hydroxyapatite structure of the tooth. Thus, there will be a formation of micromechanical retention and chemical adhesion to the hydroxyapatite structure. Besides, the well-known moisture-resistant property of RelyX ${ }^{\mathrm{TM}}$ Unicem is also one of the factors that lead to the superior bond strength values of this cement since moisture control is often compromised and hard to be controlled in root canals due to their anatomical structure [29]. The mechanical properties of cement are also affected by the degree of conversion and polymerization mode. It has been proven that a dual-cured cement such as RelyX ${ }^{\mathrm{TM}}$ Unicem exhibits more superior properties, the lowest contraction stress as well as higher degrees

\section{Rasprava}

Rezultati dobiveni u ovom istraživanju pokazali su da su Parapost Fiber Lux ${ }^{\mathrm{TM}}$ i RelyX ${ }^{\mathrm{TM}}$ Unicem cement postizali veću vlačnu čvrstoću od cemenata GC everStick'POST i G$\mathrm{CEM}^{\mathrm{TM}}$. Zato rezultati ovoga istraživanja in vitro zahtijevaju odbacivanje nulte hipoteze jer postoje značajne razlike u vlačnoj čvrstoći između različitih cemenata. Istraživanje koje su proveli Yahya i suradnici također je pokazalo da je najveća vezna čvrstoća postignuta cementom Rely ${ }^{\mathrm{TM}}$ Unicem u usporedbi s cinkfosfatnim cementima Elite $100^{\circ}$, Calibra i RelyX ARC [27]. Dobra vezna čvrstoća zabilježena je i pri uporabi cementa Rely $\mathrm{X}^{\mathrm{TM}}$ Unicem [28]. Mnogo je mogućih objašnjenja u vezi s najvećom veznom čvrstoćom cementa RelyXTM Unicem u usporedbi s nekoliko drugih. Glavni razlog mogu biti samojetkajuća svojstva RelyX ${ }^{\mathrm{TM}}$ Unicema zbog sadržaja metakrilata fosforne kiseline koji je kiseo i može izazvati demineralizaciju površine zuba. Nakon procesa demineralizacije slijedi infiltracija cementa u zubnu strukturu i stvaranje kemijskih veza s hidroksiapatitom. Tako se stvara mikromehanička retencija i kemijska adhezija na strukturi hidroksiapatita. Uz to, poznato svojstvo RelyX ${ }^{\mathrm{TM}}$ Unicema - otpornost na vlagu, također je jedan od čimbenika koji dovode do vrhunskih vrijednosti vezne čvrstoće ovog cementa jer je kontrola vlage često otežana i teško se kontrolira u korijenskim kanalima zbog njihove anatomske strukture [29]. Na mehanička svojstva cementa utječe i stupanj konverzacije i način polimerizacije. Dokazano je da dualno stvrdnjujući cement kao što je RelyX ${ }^{\mathrm{TM}}$ Unicem ima superiorna svojstva, najmanje kontrakcijsko naprezanje te veći stupanj konverzije u usporedbi s cementima s drugim načinom polimerizacije $(29-32)$.

Test vlačne čvrstoće u ovom istraživanju također je otkrio da kolčić FiberLux ima veću vrijednost vezne čvrstoće od kol- 
of conversion as compared to cements with another polymerization mode [29-32].

The Push-out bond strength test in this study has also revealed that Parapost FiberLux post has a greater bond strength value than GC everStick'POST when cemented with either G- CEM ${ }^{\mathrm{TM}}$ or Rely $\mathrm{X}^{\mathrm{TM}}$ Unicem. This indicates that stronger adhesion has occurred between Parapost FiberLux posts with both types of luting cement used, as compared to GC everStick'POST. In agreement with this result, a previous study by Alnaqbi et al. [33] has also found that the everStick'POST recorded a lower bond strength than RelyX Fiber post. Another previous study has also obtained a similar result where RelyX Fiber post has a higher bond strength when cemented with Rely $\mathrm{X}^{\mathrm{TM}}$ Unicem than that recorded of GC everStick"POST when cemented with similar types of luting cements [34]. There are several mechanisms that contribute to the adhesion between the fiber posts and resin cements, and these include micromechanical interlocking, chemical bonding and inter-diffusion [33]. The high elasticity properties of fiber-reinforced posts make the strain generated to be greatly reduced [35] and also provides the post with similar physical properties as natural dentin [10]. However, it is difficult for the posts with a cross-linked dimethacrylate-based or epoxy-based matrix to chemically bond to the luting resin cements due to the high cross-linking density properties since the monomers of the luting cement are unable to penetrate into the polymer matrix with a cross-linked nature $[36,37]$. Thus, the inter-diffusion mechanism does not play a role in the process of adhesion of fiber posts to cross-linked epoxy-based fiber-reinforced posts.

For GC everStick"POST, it consists of a semi-interpenetrating polymer network (IPN), whereby there are two independent polymer networks that are not linked by chemical bonds [38]. The manufacturer has claimed that the bond of everStick POST with the pre-polymerized semi-IPN and the resin cements are improved by the mechanism of interdiffusion bonding. When the resin cements are in contact with the surface of the IPN resin matrix, the monomers of the cement diffuse into the linear phases of the IPN polymer matrix, and the polymerization then becomes inter-locked. EverStick'POST has the content of poly Bis-GMA as the cross-linked phase and polymethyl methacrylate (PMMA) as the linear phase, and the surface of everStick"POST is enriched with a layer of PMMA [37]. This partially linear phase of everStick"POST is what makes it possible for the inter-diffusion bonding process to occur since this inter-diffusion will only happen if the polymer substrate is either a totally or partially linear polymer [38]. The types of cement used in our study had solubility parameters close to PMMA, thus providing an advantage for deeper penetration into the semiIPN polymer structure of everStick POST and contributing to great resistance to fractural strength [33].

According to Zhang and Matinlinna, the difference in the types of glass fiber content of these two types of posts is one of the factors that affect their mechanical properties. Parapost ${ }^{\circ}$ Fiber Lux ${ }^{\mathrm{TM}}$ post contains S-glass fibers that are known to have the greatest tensile strength among all types of glass fibers. As for GC everStick POST, this post has the E-glass čića GC everStickPOST kada se pričvršćuje cementima G$\mathrm{CEM}^{\mathrm{TM}}$ ili RelyX $\mathrm{X}^{\mathrm{TM}}$ Unicem. To upućuje na to da se dogodila jača adhezija između kolčića Parapost FiberLux objema vrstama cementa, u usporedbi s kolčićima GC everStick"POST. U skladu s tim rezultatom, istraživanje Alnaqbija i suradnika [33] također je pokazalo da je everStick'POST postigao slabiju veznu čvrstoću u odnosu prema RelyX Fiberu. U jednom drugom istraživanju također je dobiven sličan rezultat - RelyX Fiber imao je veću veznu čvrstoću kada je bio pričvršćen cementom RelyX ${ }^{\mathrm{TM}}$ Unicem negoli GC everStick'POST kad je cementiran sličnim vrstama cemenata [34]. Nekoliko mehanizama pridonosi adheziji između vlakana i cementa, a oni uključuju mikromehaničko spajanje, kemijsko vezivanje i inter-difuziju (33). Visoka elastičnost kompozitnih kolčića ojačanih vlaknima čine da se generirano naprezanje znatno smanji (35), a također imaju slična fizička svojstva kao prirodni dentin [10]. Teško će se kolčići s umreženom matricom na bazi dimetakrilata ili epoksidne smole kemijski vezati na kompozitne cemente zbog velike gustoće jer monomeri iz cementa ne mogu prodrijeti u umreženu polimernu matri$\mathrm{cu}(36,37)$.

GC everStick'POST sastoji se od poluinterpenetrirajuce polimerne mreže (IPN), pri čemu postoje dvije zasebne polimerne mreže koje nisu povezane kemijskim vezama (38). Proizvođač tvrdi da je veza everStick'POST-a s prepolimeriziranim polu-IPN-om i adhezijskim cementom poboljšana mehanizmom interdifuzijskog vezanja. Kad su kompozitni cementi u kontaktu s površinom IPN-a smolaste matrice, monomeri cementa difundiraju u linearnu fazu IPN-a i polimerizacijom se uzajamno zaključavaju. EverStick"POST sadržava poli-bis-GMA kao umreženu fazu i polimetilmetakrilat (PMMA) kao linearnu fazu, a površina everStick"POST-a obogaćena je slojem PMMA-e (37). Ta djelomično linearna faza omogućuje postupak inter-difuzijskog povezivanja jer će se ta difuzija dogoditi samo ako je polimerni supstrat potpuno ili djelomično linearan (38). Vrste cementa korištene u našem istraživanju imale su parametre topljivosti slične PMMA-i, što omogućuje prednost u obliku dubljeg prodiranja u polu-IPN polimernu strukturu everStick'POST-a i pridonosi velikoj čvrstoći (33).

Prema stajalištu Zhanga i Matinlinnija razlika u sadržaju staklenih vlakana u tim dvjema vrstama kolčića jedan je od čimbenika koji utječu na njihova mehanička svojstva. Parapost Fiber Lux ${ }^{\mathrm{TM}}$ sadržava tip $S$ staklenih vlakana za koja se zna da postižu najveću vlačnu čvrstoću među svim vrstama staklenih vlakana. Kad je riječ o kolčićima GC everStick"POST, oni sadržavaju tip E-staklenih vlakana za koji se zna da postižu manju vlačnu čvrstoću u odnosu prema S-vlaknima [39]. Drugi mogući razlog jest razlika u obliku samog kolčića. Parapost Fiber LuxTM se sužava, pri čemu ima cilindričnu konfiguraciju koronarno i koničnu konfiguraciju apikalno. To oponaša prirodnu anatomsku strukturu korijenskog kanala te dodatno poboljšava prilagodbu kolčića u korijenskom kanalu. No GC everStick'POST paralelnog je oblika i manje oponaša anatomiju korijenskog kanala, a katkad, kao u slučaju proširenog kanala, može biti potrebno više od jednog kolčića po kanalu. Zato se može pretpostaviti da je to možda jedan od razloga za dobru veznu čvrstoću 
fibers type, which is known to have a lower tensile strength compared to S-glass fibers [39]. Another possible reason is the difference in the shape of the post itself. Parapost Fiber $\mathrm{Lux}^{\mathrm{TM}}$ post is tapered in shape whereby it has a cylindrical configuration coronally and conical configuration apically. This closely mimics the natural anatomical structure of the root canal, thus further enhancing the adaptation of the post in the root canal. However, GC everStick POST is parallel in shape which less mimics the anatomy of the root canal, and in certain cases such as in widened canal, more than a single post may be required to be packed into the canal. In this way, it may be hypothesized that this may be one of the reasons behind the superior bond strength of Parapost Fiber Lux ${ }^{\mathrm{TM}}$ compared to GC everStick'POST [34].

Although the middle third of the root had higher pushout bond strength than coronal third irrespective the type of post or cement, this difference was in favor of the coronal part when the type of cement was considered. Therefore, the push-out bond strength of the coronal third cemented with Rely $\mathrm{X}^{\mathrm{TM}}$ Unicem cement was higher than the middle third cemented with GC- CEM ${ }^{\mathrm{TM}}$ cement. This result is comparable to that obtained by Pereira et al. [40] where a significant difference was noticed with different types of cement. This might be attributed to the number of dentinal tubules in the coronal third of the root, which is higher and decreasing gradually towards the apical third [41]. This, in turn, might enhance the adhesion of the cement to the dentin by penetration of the resin to dentin tubules [3]. Some limitations of the current study should be acknowledged. The results are restricted to specific products, hence we cannot make generalizations about all other products. The environment of in-vitro studies is somewhat different from the clinical situation, therefore, further clinical follow-up studies are recommended to simulate the real circumstances.

\section{Conclusion}

Within the limitations of this in-vitro study, it can be concluded that the type of cement had a significant effect on push-out bond strength with RelyX ${ }^{\mathrm{TM}}$ Unicem cement being significantly more adhesive than GC- $\mathrm{CEM}^{\mathrm{TM}}$ cement. However, the type of post and root level had no significant effect on PBS, although Parapost ${ }^{\oplus}$ Fiber $\mathrm{Lux}^{\mathrm{TM}}$ and the middle root level had higher values than their counterparts.

\section{Conflicts of Interests}

No potential conflict of interest relevant to this article was reported.

\section{Acknowledgments}

The authors would like to acknowledge the support of University Sains Malaysia (USM) Fellowship.

\section{Funding}

This study was funded by Research University Grant 1001/PPSG/8012282. kolčića Parapost Fiber LuxTM u usporedbi s kolčicíima GC everStick'POST (34).

Iako je srednja trećina korijena imala veću veznu čvrstoću u odnosu prema koronarnoj trećini, bez obzira na vrstu kolčića ili cementa, ta je razlika bila u korist koronarnog dijela kada se razmatrala vrsta cementa. Zato je vlačna čvrstoća u koronarnoj trećini nakon pričvršćivanja cementom RelyX ${ }^{\mathrm{TM}}$ Unicem bila veća negoli u srednjoj trećini nakon pričvršćivanja cementom GC-CEM ${ }^{\mathrm{TM}}$. Taj se rezultat može usporediti $s$ rezultatima Pereire i suradnika (40) koji su uočili značajnu razliku kod različitih vrsta cementa. To bi se moglo pripisati broju dentinskih tubula u koronarnoj trećini korijena koji je veći i postupno opada prema apikalnoj trećini (41). To može poboljšati adheziju cementa na dentin prodiranjem smole u dentinske tubule (3).

Treba priznati i neka ograničenja u ovom istraživanju. Rezultati su ograničeni na specifične proizvode i zato se ne mogu odnositi na sve ostale proizvode. Uvjeti istraživanja in vitro donekle se razlikuju od kliničke situacije te se preporučuju daljnja klinička istraživanja za simulaciju stvarnih uvjeta.

\section{Zaključak}

Uzimajući u obzir ograničenja ovoga istraživanja in vitro može se zaključiti da je vrsta cementa značajno utjecala na veznu čvrstoću, pri čemu se cementom RelyX ${ }^{\mathrm{TM}}$ Unicem postizala bolja adhezija negoli cementom GC-CEM ${ }^{\mathrm{TM}}$. No vrsta kolčića i razina korijena nisu značajano utjecali na PBS, iako su Parapost Fiber Lux ${ }^{\mathrm{TM}}$ i srednja razina korijena imali veće vrijednosti od ostalih skupina.

\section{Sukob interesa}

Autori nisu bili u sukobu interesa.

\section{Zahvale}

Autori zahvaljuju na stipendiji Sveučilištu Sains, Malezija (USM).

\section{Financiranje}

Istraživanje je financiralo Istraživačko sveučilište Grant 1001 / PPSG / 8012282. 


\section{Contribution to the paper}

M.N.A. participated in the design of the study, data collection, statistical analysis, interpretation of the data, and drafted the manuscript; N.S.S. participated in data collection, interpretation of the data, and drafted the manuscript; Y.J., M.S., N.A.A., and Z.A. participated in the design of the study, interpretation of the data and drafted the manuscript.

All authors of this paper have read and approved the final version submitted.

\section{Doprinos radu}

M. N. A. - sudjelovao je u dizajniranju istraživanja, prikupljanju podataka, statističkoj analizi, interpretaciji podataka i izradi rukopisa; N. S. S. - sudjelovao je su prikupljanju podataka, njihovoj interpretaciji i izradi rukopisa; Y. J., M. S., N. A. A. i Z. A. - sudjelovali su u dizajniranju istraživanja, interpretaciji podataka i izradi rukopisa.

Svi autori ovoga rada pročitali su i odobrili konačnu verziju teksta.

\section{Sažetak}

Cilj: Endodontski liječeni zubi mogu zahtijevati izradu nadogradnje za osiguravanje retencije i nadomještanje izgubljenoga zubnog tkiva. Cilj ovog istraživanja bio je procijeniti i usporediti vlačnu čvrstoću različitih vrsta intrakanalnih kolčića pričvršćenih različitim vrstama cementa na različitim razinama korijena. Materijal i metode: $\mathrm{U}$ ovom istraživanju in vitro dekoronirano je ukupno 48 jednokorijenskih trajnih ljudskih zuba, a korijeni su endodontski izliječeni. Nakon preparacije prostora za nadogradnju uzorci su podijeljeni u četiri skupine ( $n=12$ svaka) na temelju vrste kolčića i cementa. Dvije različite vrste kolčića (GC everStick ${ }^{\oplus}$ POST (ES) i Parapost ${ }^{\circledR}$ Fiber Lux $\left.{ }^{\top M}(P F)\right]$ te dvije različite vrste cementa [G-CEM ${ }^{\top M}$ $(G)$ i RelyX ${ }^{T M}$ Unicem (R)] korištene su prema uputama proizvođača. Svi korijeni prerezani su u koronarnoj i srednjoj trećini na debljinu od $3 \pm 0,1 \mathrm{~mm}$. Ispitivanje vlačne čvrstoće provedeno je na univerzalnoj kidalici s brzinom okretanja glave od $0,5 \mathrm{~mm} / \mathrm{min}$. Zabilježene su vrijednosti vezne čvrstoće, a podatci su analizirani u programu SPSS. Osim deskriptivne statistike, upotrijebljena je trosmjerna ANOVA za analizu interakcija neovisnih varijabli (vrsta kolčića, cement i razina korijena). Za razlike među skupinama primijenjen je Mann-Whitneyev U-test. P-vrijednost manja od 0,05 smatrala se statistički značajnom za sve analize. Rezultati: Vlačna čvrstoća uzoraka na srednjoj razini korijena $(11,38 \pm 10,31 \mathrm{MPa})$ s PF kolčićima (11,18 $\pm 9,98 \mathrm{MPa})$ pričvršćenima cementom RelyX $X^{\top \mathrm{M}}$ Unicem $(13,26 \pm 8,73 \mathrm{MPa})$ bila je veća u usporedbi s drugim skupinama. Srednje vrijednosti za PBS RelyX ${ }^{\top M}$ Unicem na objema razinama korijena bile su mnogo veće negoli za G-CEM ${ }^{\top M}$. Trosmjerna ANOVA pokazala je značajan učinak za svaku varijablu s većim učinkom cementa (zbroj kvadrata =1310.690; $P<0,001$ ). Nije utvrđena značajna razlika $(P=0,153)$ između koronarnog i srednjeg dijela te između stupaca ES i $P F(P=0,058)$. No zabilježena je značajna razlika $(P<0,001)$ između cementa RelyX ${ }^{T M}$ Unicem i G-CEM ${ }^{\text {TM }}$. Zaključak: Vrsta cementa znatno je utjecala na vlačnu čvrstoću pri čemu je RelyX ${ }^{\top M}$ Unicem imao veće vrijednosti negoli G-CEM ${ }^{T M}$. No vrsta kolčića i razina korijena nije imala značajan utjecaja na PBS, iako su Parapost ${ }^{\circledR}$ Fiber Lux $^{\mathrm{TM}}$ i srednja razina korijena imali više vrijednosti u usporedbi s ostalim skupinama.
Zaprimljen: 29. travnja 2020. Prihvaćen: 24. lipnja 2020.

Adresa za dopisivanje Associate Professor Zaihan Ariffin, DClin Dentistry School of Dental Sciences, Health Campus, University Sains Malaysia, 16150 Kubang Kerian, Kelantan, Malaysia zaihan@usm.my

Ključne riječ

stomatološki cementi; dentinski adhezivi; vlačna čvrstoća; tehnika kolčić-nadogradnja

\section{References}

1. Standlee JP, Caputo AA. Endodontic dowel retention with resinous cements. J Prosthet Dent. 1992;68:913-7.

2. Das AKAK, Muddugangadhar B, Amarnath G, Garg A, Kumar U, Rao TP. Comparative evaluation of push out bond strength of a fiber post system using four different resin cements: An in-vitro study. J Int Oral Health. 2015;7(Suppl 1):62-7.

3. Chappell RP, Cobb CM, Spencer P, Eick JD. Dentinal tubule anastomosis: a potential factor in adhesive bonding? J Prosthet Dent. 1994 Aug;72(2):183-8.

4. Tjan AH, Whang SB. Resistance to root fracture of dowel channels with various thicknesses of buccal dentin walls. J Prosthet Dent. 1985 Apr;53(4):496-500.

5. Monticelli F, Grandini S, Goracci C, Ferrari M. Clinical Behavior Translucent-Fiber Posts: A 2-Year Prospective Study. Int J Prosthodont. Nov-Dec 2003;16(6):593-6.

6. Muttlib NA, Azman AN, Seng YT, Alawi R, Ariffin Z. Intracanal Adaptation of a Fiber Reinforced Post System as Compared to a Cast Post-and-Core. 2016 Dec;50(4):329-336.

7. Yoshiyama M, Matsuo T, Ebisu S, Pashley D. Regional bond strengths of self-etching/self-priming adhesive systems. J Dent. 1998 Sep;26(7):609-16.

8. Malferrari S, Monaco C, Scotti R. Clinical Evaluation of Teeth Restored with Quartz Fiber--Reinforced Epoxy Resin Posts. Int J Prosthodont. Jan-Feb 2003;16(1):39-44.

9. D’Arcangelo C, Cinelli M, De Angelis F, D’Amario M. The effect of resin cement film thickness on the pullout strength of a fiber-reinforced post system. 2007 Sep;98(3):193-8.

10. Lamichhane A, Xu C, Zhang F. Dental fiber-post resin base material: a review. J Adv Prosthodont. 2014;6:60-5.

11. Drummond JL, Bapna MS. Static and cyclic loading of fiber-reinforced dental resin. 2003 May;19(3):226-31.

12. Lassila LV, Tanner J, Le Bell A-M, Narva K, Vallittu PK. Flexural properties of fiber reinforced root canal posts. Dent Mater. 2004;20:29-36
13. Ferrari M, Vichi A, Mannocci F, Mason PN. Retrospective study of the clinical performance of fiber posts. Am J Dent. 2000 May;13(Spec No):9B-13B.

14. Baran G, Boberick K, McCool J. Fatigue of restorative materials. Crit Rev Oral Biol Med. 2001;12(4):350-60.

15. Crispim da Silveira O, Bras da Silva R, Dametto FR, Machado CT, Souza Dos Santos AJ, et al. Effect of Endodontic Irrigating Solutions on the Micro Push-out Bond Strength of a Fibre Glass Dowel. Acta Stomatol Croat. 2014 Mar;48(1):16-24.

16. Parčina I, Amižić, Miletić I, Ionescu AC, Brambilla E, Gabrić D, et al. Influence of Laser Activated Irrigation with two Erbium Lasers on Bond Strength of Inidividually Formed Fiber Reinforced Composite Posts to Root Canal Dentin. Acta Stomatol Croat. 2016;50:3218.

17. Vichi A, Grandini S, Ferrari M. Comparison between two clinical procedures for bonding fiber posts into a root canal: a microscopic investigation. J Endod. 2002 May;28(5):355-60.

18. Sidoli GE, King PA, Setchell DJ. An in vitro evaluation of a carbon fiber-based post and core system. J Prosthet Dent. 1997;78:5-9.

19. Zicari F, Couthino E, De Munck J, Poitevin A, Scotti R, Naert I, et al. Bonding effectiveness and sealing ability of fiber-post bonding. Dent Mater. 2008 Jul;24(7):967-77.

20. Kececi AD, Kaya BU, Adanir N. Micro push-out bond strengths of four fiber-reinforced composite post systems and 2 luting materials. Oral Surg Oral Med Oral Pathol Oral Radiol Endod. 2008 Jan;105(1):121-8.

21. Bitter K, Kielbassa AM. Post-endodontic restorations with adhesively luted fiber-reinforced composite post systems: a review. Am J Dent. 2007 Dec;20(6):353-60.

22. Mazzoni A, Marchesi G, Cadenaro M, Mazzotti G, Di Lenarda R, Ferrari $\mathrm{M}$, et al. Push-out stress for fibre posts luted using different adhesive strategies. Eur J Oral Sci. 2009 Aug;117(4):447-53.

23. Sterzenbach G, Karajouli G, Naumann M, Peroz I, Bitter K. Fiber post placement with core build-up materials or resin cements- 
An evaluation of different adhesive approaches. Acta Odontol Scand. 2012 Sep;70(5):368-76.

24. Beltagy TM. Fracture resistance of rehabilitated flared root canals with anatomically adjustable fiber post. Tanta Dent J. 2017;14:96.

25. Saad AY, Al-Hadlaq SM, Al-Katheeri NH. Efficacy of two rotary NiTi instruments in the removal of Gutta-Percha during root canal retreatment. J Endod. 2007 Jan;33(1):38-41.

26. Mosharraf R, Haerian A. Push-out bond strength of a fiber post system with two resin cements. Dent Res J (Isfahan). 2011 Dec;8(Suppl 1):S88-93.

27. Yahya NA. Effect of luting cement to push-out bond strength of fibre reinforced post. Ann Dent UM. 2018;15:11-9.

28. Gurgel-Filho ED, Lima FC, Saboia V, Coutinho-Filho T, Neves A, Silva E. Push-out bond strength of a self-adhesive resin cement used as endodontic sealer. Restor Dent Endod. 2014 Nov;39(4):282-7.

29. Özcan S, Aktuna S, Nayir Y, Yaman D, Bala O. Push-out bond strength of fiber posts luted using different adhesive resin cements. J Restor Dent. 2013;1:75.

30. Ferracane J, Greener E. The effect of resin formulation on the degree of conversion and mechanical properties of dental restorative resins. J Biomed Mater Res. 1986 Jan;20(1):121-31.

31. Vrochari AD, Eliades G, Hellwig E, Wrbas K-T. Curing efficiency of four self-etching, self-adhesive resin cements. Dent Mater. 2009 Sep;25(9):1104-8.

32. Saskalauskaite E, Tam LE, McComb D. Flexural strength, elastic modulus, and $\mathrm{pH}$ profile of self-etch resin luting cements. J Prosthodont. 2008 Jun;17(4):262-8.
33. Alnaqbi IO, Elbishari H, Elsubeihi ES. Effect of Fiber Post-Resin Matrix Composition on Bond Strength of Post-Cement Interface. Int I Dent. 2018 Dec 2;2018:4751627.

34. Pirvani M, Khan S, Malik S. Evaluation of Push Out Bond Strength of a Dual-Cure Self-Adhesive Resin-Cement with Fiber Post Systems and Dentine. J Pak Dent Assoc. 2015;24:28.

35. Asmussen E, Peutzfeldt A, Heitmann T. Stiffness, elastic limit, and strength of newer types of endodontic posts. J Dent. 1999 May;27(4):275-8.

36. Le Bell A-M, Tanner J, Lassila LV, Kangasniemi I, Vallittu PK. Bonding of composite resin luting cement to fiber-reinforced composite root canal posts. J Adhes Dent. Winter 2004;6(4):319-25.

37. Mannocci F, Sherriff M, Watson T, Vallittu P. Penetration of bonding resins into fibre-reinforced composite posts: a confocal microscopic study. Int Endod J. 2005;38:46-51.

38. Klempner D, Sperling LH, Utracki LA, editors. Interpenetrating polymer networks. American Chemical Society. Washington; 1994.

39. Zhang M, Matinlinna JP. E-glass fiber reinforced composites in dental applications. Silicon. 2012;4:73-8.

40. Pereira JR, Pamato S, Santini MF, Porto VC, Ricci WA, Só MVR. Push-out bond strength of fiberglass posts cemented with adhesive and self-adhesive resin cements according to the root canal surface. Saudi Dent J. 2019.

41. Arora J, Talwar I, Sahni D, Rattan V. Morphology and age-related changes in calcospherites of human teeth: an ultrastructural study. 2017 Jun;44(4):349-356. 